\title{
Rocky Mountain Spotted Fever in a Large Metropolitan Center, Mexico- United States Border, 2009-2019
}

\author{
Oscar E. Zazueta, Paige A. Armstrong, Adriana Márquez-Elguea, Néstor Saúl Hernández Milán, \\ Amy E. Peterson, Diego F. Ovalle-Marroquín, Maria Fierro, Rodolfo Arroyo-Machado, \\ Moises Rodriguez-Lomeli, Guillermo Trejo-Dozal, Christopher D. Paddock
}

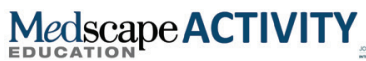

In support of improving patient care, this activity has been planned and implemented by Medscape, LLC and Emerging Infectious Diseases. Medscape, LLC is jointly accredited by the Accreditation Council for Continuing Medical Education (ACCME), the Accreditation Council for Pharmacy Education (ACPE), and the American Nurses Credentialing Center (ANCC), to provide continuing education for the healthcare team.

Medscape, LLC designates this Journal-based CME activity for a maximum of 1.00 AMA PRA Category 1 Credit(s) ${ }^{\mathrm{TM}}$. Physicians should claim only the credit commensurate with the extent of their participation in the activity.

Successful completion of this CME activity, which includes participation in the evaluation component, enables the participant to earn up to $1.0 \mathrm{MOC}$ points in the American Board of Internal Medicine's (ABIM) Maintenance of Certification (MOC) program. Participants will earn MOC points equivalent to the amount of CME credits claimed for the activity. It is the CME activity provider's responsibility to submit participant completion information to ACCME for the purpose of granting ABIM MOC credit.

All other clinicians completing this activity will be issued a certificate of participation. To participate in this journal CME activity: (1) review the learning objectives and author disclosures; (2) study the education content; (3) take the post-test with a $75 \%$ minimum passing score and complete the evaluation at http://www.medscape.org/journal/eid; and (4) view/print certificate. For CME questions, see page 1765
\end{abstract}

Release date: May 12, 2021; Expiration date: May 12, 2022

\section{Learning Objectives}

Upon completion of this activity, participants will be able to:

- Analyze symptoms of RMSF in the current study

- Assess the epidemiology of RMSF in the current study

- Evaluate the results of diagnostic testing for RMSF in the current study

- Distinguish the risk of mortality associated with RMSF in the current study

\section{CME Editor}

Terie A. Grant, BS, Copyeditor, Emerging Infectious Diseases. Disclosure: Terie A. Grant, BS, has disclosed no relevant financial relationships.

\section{CME Author}

Charles P. Vega, MD, Health Sciences Clinical Professor of Family Medicine, University of California, Irvine School of Medicine, Irvine, California. Disclosure: Charles P. Vega, MD, has disclosed the following relevant financial relationships: served as an advisor or consultant for GlaxoSmithKline.

\section{Authors}

Disclosures: Oscar E. Zazueta, MD; Paige A. Armstrong, MD, MHS; Adriana Márquez-Elguea, MD; Néstor Saúl Hernández Milán, MD, PhD; Amy E. Peterson, DVM, PhD; Diego F. Ovalle-Marroquín, MD; Maria Fierro, MD, MPH; Rodolfo Arroyo-Machado, RN; Moises Rodriguez-Lomeli, MD; Guillermo Trejo-Dozal, MD; and Christopher D. Paddock, MD, MPHTM, have disclosed no relevant financial relationships.

Author affiliations: Secretariat of Health of Baja California (Instituto de Servicios de Salud Pública del Estado de Baja California), Mexicali, Mexico (O.E. Zazueta, A. Márquez-Elguea, N.S.H. Milán, D.F. Ovalle-Marroquín, R. Arroyo-Machado, M. Rodriguez-Lomeli, G. Trejo-Dozal); Centers for Disease Control and Prevention,
Atlanta, Georgia, USA (P.A. Armstrong, A.E. Peterson, C.D. Paddock); Imperial Country Public Health Department, EI Centro, California, USA (M. Fierro)

DOI: https://doi.org/10.3201/eid2706.191662 
Epidemic levels of Rocky Mountain spotted fever (RMSF) have persisted in Mexicali, Mexico, since the initial outbreak was first reported in December 2008. We compared clinical and epidemiologic data of cases in Mexicali during 2009-2019 between patients with an IgG titer reactive with Rickettsia rickettsii bacteria by indirect immunofluorescence antibody (IFA) assay and those who demonstrated DNA of $R$. rickettsii in a whole blood sample when tested by PCR. We identified 4,290 patients with clinical and epidemiologic features compatible with RMSF; of these, $9.74 \%$ tested positive by IFA and $8.41 \%$ by PCR. Overall, 140 patients died (11-year case-fatality rate $17.97 \%$ ). Substantial differences in the frequency of commonly recognized clinical characteristics of RMSF were identified between PCR-positive and IFA-positive cases. The Mexicali epidemic is unique in its size and urban centralization. Cases confirmed by PCR most accurately reflect the clinical profile of RMSF.

$\mathrm{R}$ ocky Mountain spotted fever (RMSF), a severe and potentially deadly tickborne disease caused by Rickettsia rickettsii bacteria, occurs throughout the Americas. The classic epidemiology of RMSF is characterized by isolated and sporadic cases of disease that occur predominantly in rural or suburban settings (1). Occasionally, regional endemic foci of infection are described, which can persist for years, or sometimes decades (2). During the early 2000s, investigators identified multiple outbreaks of RMSF among several small communities in Arizona in the United States and in Sonora, Mexico (3-6). A feature common to each of these outbreaks has been the presence of large populations of stray and free-ranging dogs heavily infested with ticks. In these settings, canine populations can sustain and perpetuate massive numbers of brown dog ticks (Rhipicephalus sanguineus sensu lato), which serve as efficient vectors of $R$. rickettsii bacteria.

In December 2008, cases of RMSF were first recognized among residents of a neighborhood in Mexicali, the capital city of Baja California, Mexico $(7,8)$. During the next few years, cases were identified in adjacent and distant neighborhoods. In contrast to almost all previously described outbreaks of RMSF, this epidemic emerged within a large metropolitan center, continues in the present day, and has affected hundreds of persons throughout the city. Cases of RMSF are now also reported beyond the city limits from several small communities in the Mexicali Valley $(9,10)$.

The ongoing epidemic of RMSF in Mexicali resembles past and present outbreaks in Arizona and northern Mexico. Cases of disease occur primarily in impoverished neighborhoods, where the presence of large populations of stray dogs infested with infected brown dog ticks greatly increase the human risk for exposure to the pathogen (10-13). Efforts to document the scope and magnitude of RMSF in Mexicali have been hampered by limited access to sensitive and specific diagnostic techniques, the relatively nonspecific clinical findings observed during the early stages of illness, and incomplete awareness among many residents and local health care providers of the regional risk and scope of the epidemic (10). To more accurately characterize the epidemiology of RMSF in Mexicali, we compiled and analyzed data available for all cases with serologic or molecular evidence of infection that were reported to the Secretariat of Health of Baja California (ISESALUD) during 2009-2019.

\section{Methods}

\section{Setting}

Mexicali is located at the Mexico-United States border, adjacent to the California town of Calexico. According to the National Institute of Statistics and Geography in Mexico, this large urban center extends across $114 \mathrm{~km}^{2}$ and has a population of $\approx 700,000$ persons. The Mexicali Valley, comprising 13,700 $\mathrm{km}^{2}$, extends southeast of the city and is inhabited by $\approx 250,000$ persons. Most city residents receive their medical care at hospitals and clinics operated by the Mexican Institute of Social Security (60\%), ISESALUD $(21 \%)$, and the Institute for Social Security and Services for State Workers (13\%) (14).

\section{Collection of Data}

We analyzed clinical and epidemiologic data for all cases of RMSF reported to ISESALUD in the Mexicali metropolitan area and the Mexicali Valley during 2009-2019 by abstracting data retrospectively from the standardized case report used by the Mexicali General Hospital and Ministry of Health clinics across the city (15) and all major hospitals in the area. Case definitions are established nationwide by the Directorate General of Epidemiology (DGE) $(15,16)$. A probable case is defined as fever $\left(>38.5^{\circ} \mathrm{C}\right)$ and $\geq 2$ of the following signs or symptoms: headache, myalgia, rash, purpura, meningeal signs, alterations in cerebrospinal fluid, hemorrhage, liver enzyme abnormality, hematologic alterations, hyponatremia, leukocytosis, leukopenia, elevated levels of lactate dehydrogenase, or shock. Cases also require $\geq 1$ of the following epidemiologic criteria during the 2 weeks preceding illness onset: history of tick bite or direct contact with a tick-infested dog, ticks identified in or around the patient's household, or travel to or 
residence in a neighborhood where cases of RMSF had been recently identified. Confirmed cases include those in patients with a serum IgG titer $\geq 64$ to $R$. rickettsii antigens, determined by an indirect immunofluorescence antibody (IFA) assay on serum samples, and those for whom PCR evaluation of a whole blood specimen demonstrates DNA of a spotted fever group Rickettsia (SFGR). For this investigation, we compared frequencies of clinical and epidemiologic characteristics identified for those patients with a positive PCR result with those identified by a positive IFA result.

\section{Laboratory Testing}

During 2009, serum specimens were serially diluted beginning at 1:80; for all subsequent years, 1:64 was used as the first dilution. Antibody titers were expressed as the reciprocal of the last reactive dilution, and titers $\geq 64$ were considered positive. Molecular analyses were performed by using a Rickettsia genusspecific real-time assay targeting a 74-bp segment of the citrate synthase gene and primers CS-F and CS-R and probe CS-P, as previously described (17). Samples with cycle threshold values $<38$ were considered positive on the basis of the cutoff for this assay established by the Mexico Secretariat of Health, Institute of Epidemiological Diagnosis and Reference.

\section{Mapping and Statistical Analyses}

We transformed physical addresses of PCR-positive case-patients into geographic coordinates by using an automated algorithm developed by Mexico's National Institute of Statistics and Geography. We created maps using Epi Info 7 (Centers for Disease Control and Prevention, https://www.cdc.gov/epiinfo). We described categorical variables as counts and proportions and continuous variables by using mean, median, and range. We used the $t$-test for comparisons of means and Fisher exact test for comparisons of proportions. Because of the large number of cases, we assumed that continuous data followed a normal distribution according to the central limit theorem. We did not report missing data. We used Stata 14 (StataCorp, https://www.stata.com) to perform all statistical analyses. This study was approved by the Institutional Review Board of Tijuana General Hospital (approval no. HGT-2017-000058).

\section{Results}

During 2009-2019, a total of 4,290 persons in metropolitan Mexicali and the Mexicali Valley had illnesses meeting the DGE case definition for probable cases of RMSF (Figure 1). Of those, a diagnostic assay was performed on 2,532 patients, and a positive result from either assay was recorded for 921 (36.37\%). We excluded 142: those for whom only an IgM titer was available $(n=102)$ and those for whom an IFA result was reported as positive but without a reported antibody titer $(n=40)$. Of the total probable cases identified by the surveillance case definition, 779 (18.15\%) met DGE criteria for a confirmed case, 418 (53.66\%) with a positive test result by IFA and $361(46.34 \%)$ by PCR (Table 1). For 341 confirmed cases, only PCR was performed, for 417 only IFA, and for 21 both tests. Of those tested by PCR and IFA, 20 had positive results with both assays, and 1 was negative by PCR but positive by IFA.

The median time from illness onset until the collection of whole blood for PCR and serum for IFA was 5 days (interquartile range [IQR] 3-8 days). The geometric mean titers of IFA-positive cases were 175 during 2009-2011, 231 during 2012-2015, and 156 during 2016-2019. Approximately two thirds (64.2\%) of positive serum samples were collected during the first week of illness.

Nearly half $(378,48.52 \%)$ of all positive casepatients resided in the city of Mexicali. The remaining case-patients originated from several neighborhoods adjacent to but beyond the city limits (243 $[31.19 \%])$, the region of Puebla (57 [7.32\%]), and from the Mexicali Valley (101 [12.97\%]). The cumulative 11-year average incidence rate of RMSF during this period, including PCR- and IFA-confirmed cases, was $7.22 / 100,000$ population/year (1.76-29.16/100,000 population/year) (Figure 2).

Among all confirmed case-patients, the mean age was 23.89 years (SD 17.65, IQR 9-36 years), which did not differ significantly between those whose cases were confirmed by IFA or PCR. Most patients (440 [56.48\%]) were female. Cases occurred during each month of the year but were more frequent during the summer months (Figure 3). A disproportionately higher number of IFA-confirmed cases were identified during February and March; nonetheless, 156 (37.32\%) of all IFA-positive cases were reported during early 2009, shortly after the outbreak was first recognized and before widespread access to confirmatory PCR assays. A total of 410 case-patients were hospitalized, $271(66.1 \%)$ of whom were confirmed by PCR only, $123(30 \%)$ by IFA only, and $16(3.9 \%)$ by both assays. The mean length of stay of hospitalized case-patients was 8.89 days (median 5 days, IQR 1-11 days), a mean of 9.23 days for PCR-confirmed patients and 7.33 days for IFA-confirmed patients $(\mathrm{p}=0.20)$.

Overall, 140 patients died (11-year case-fatality rate $17.97 \%): 125$ (89.28\%) whose illness was diagnosed 


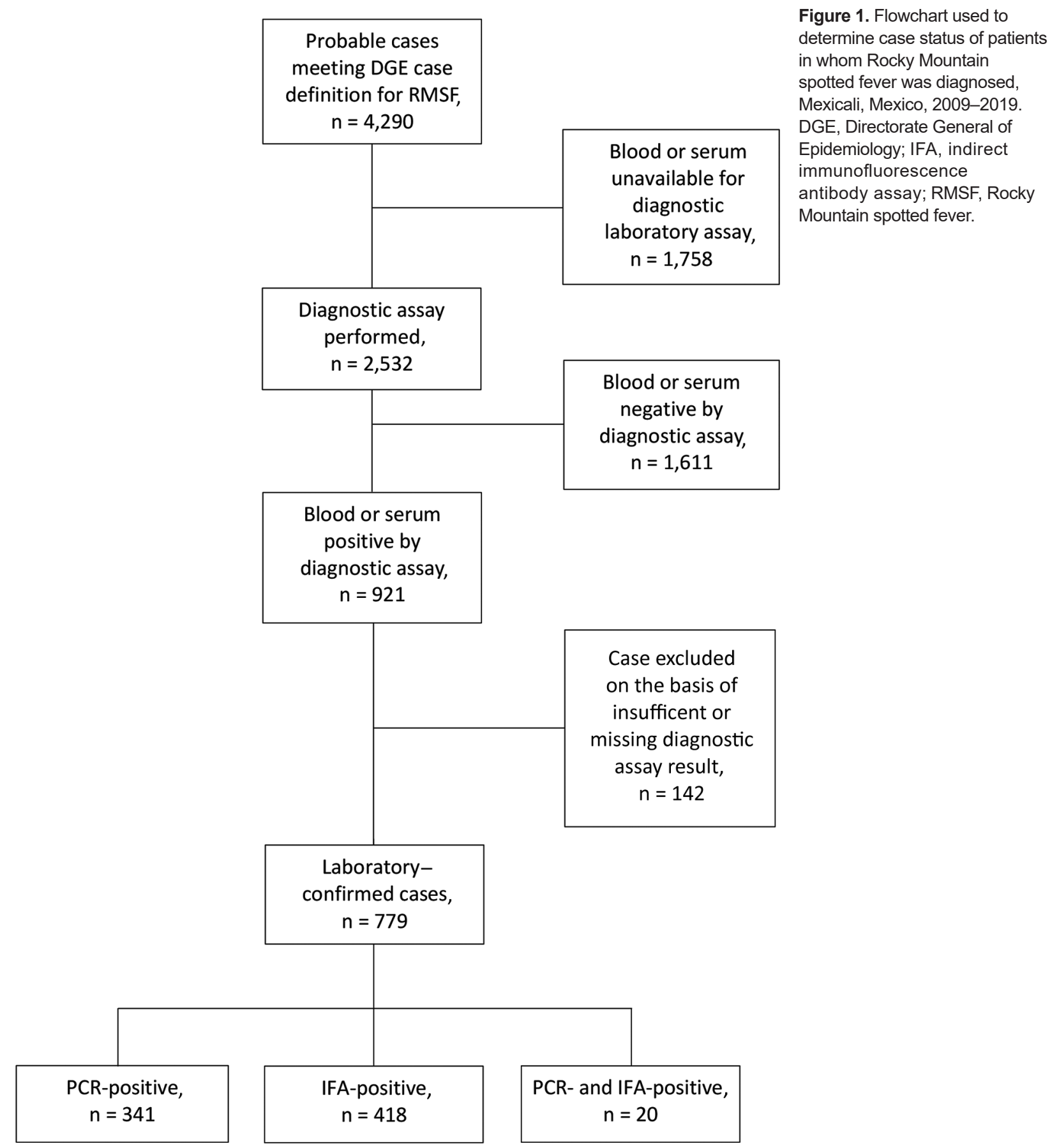

by PCR only, $11(7.86 \%)$ by IFA only, and 4 (2.86\%) by both assays. Approximately one quarter of deaths occurred among children $\leq 15$ years of age (Table 2). The case-fatality rate was $36.66 \%$ for PCR-positive and $2.63 \%$ for IFA-positive patients $(p<0.001)$. PCRconfirmed case-patients were significantly more likely to be admitted to a hospital $(\mathrm{p}<0.001)$ and die from their infections than were case-patients confirmed by IFA (Table 3).
Among patients with laboratory-confirmed cases, the predominant signs and symptoms were fever $(100 \%)$, headache $(86.43 \%)$, myalgia $(61.66 \%)$, arthralgia (53.10\%), nausea $(48.22 \%)$, abdominal pain $(45.45 \%)$, and rash $(43.27 \%)$. However, statistically significant differences were identified in the frequencies of several of these features, and many other clinical findings, when comparing PCR-positive versus IFA-positive patients (Table 3). 
Rocky Mountain Spotted Fever, Mexico

Table 1. Frequency of laboratory-confirmed cases of Rocky Mountain spotted fever by assay, Mexicali, Mexico, 2009-2019*

\begin{tabular}{|c|c|c|c|c|}
\hline \multirow[b]{2}{*}{ Period } & \multicolumn{3}{|c|}{ No. (\%) } & \multirow[b]{2}{*}{ Total no. cases } \\
\hline & PCR-positive & IFA-positive & PCR- and IFA-positive & \\
\hline 2009-2011 & $73(20.74)$ & $275(78.13)$ & $4(1.14)$ & 352 \\
\hline $2012-2015$ & $172(56.95)$ & $114(37.75)$ & $16(5.30)$ & 302 \\
\hline 2016-2019 & $96(76.80)$ & $29(23.20)$ & $0(0)$ & 125 \\
\hline Total & $341(43.77)$ & $418(53.66)$ & $20(2.57)$ & 779 \\
\hline
\end{tabular}

Geospatial analysis of PCR-confirmed cases during the periods 2009-2011, 2012-2015, and 2016-2019 revealed marked expansion of recognized cases across Mexicali. During the first 3 years of the outbreak, cases were concentrated predominantly in the western part of the city from where the index case originated in 2008. During 2012-2015, cases were subsequently identified in the southern portion of the city (Figure 4, panel A) and the region of Puebla in southeastern Mexicali. The Mexicali Valley also experienced progressively more cases during 2016-2019 (Figure 4, panel B). Cases have been identified in almost every neighborhood of Mexicali over the course of the epidemic, often repeatedly in the same areas over time.

\section{Discussion}

The epidemiology of RMSF in Mexicali shares many features of epidemic RMSF identified previously among communities in other regions of southwestern North America (3-6,13). During the 1940s, investigators in Mexico were the first to identify and characterize the ecologic, epidemiologic, and social determinants of outbreaks of RMSF that emerged among small and impoverished communities of Sinaloa, Sonora, Durango, and Coahuila. These highly lethal outbreaks, ignited by unchecked canine populations that supported massive peridomestic infestations by brown dog ticks, resulted in high attack rates among women and children and ended in death for most infected patients $(13,18,19)$. Contemporary outbreaks in Sonora and Coahuila also involve predominantly economically vulnerable populations and are particularly devastating among children, for whom mortality rates range from $30 \%$ to $57 \%(13,20$ 22). The Mexicali epidemic is similarly represented by a large number of pediatric patients and a nearly $37 \%$ case-fatality rate among PCR-positive cases. The year-round occurrence of the disease, with notable peaks during the summer and fall months, also reflects the previously described seasonal pattern of RMSF in northern Mexico.

The Mexicali epidemic is unique from all previously described outbreaks of RMSF in terms of its magnitude, urban concentration, and widespread persistence. The timing and origin of the introductory event that precipitated this multiyear outbreak remains unknown. However, the circumstances that propelled its expansion and eventual perpetuation across the city, including high-density, low-income neighborhoods with large numbers of free-roaming and stray dogs and abundant brown dog tick populations, exist within many other metropolitan areas across Mexico and Latin America. In this context, similar urban outbreaks could plausibly originate elsewhere after local introduction of $R$. rickettsii. As we note, during 2009-2019, surveillance activities by ISESALUD identified 779 patients with laboratorysupported diagnoses of RMSF in Mexicali and the

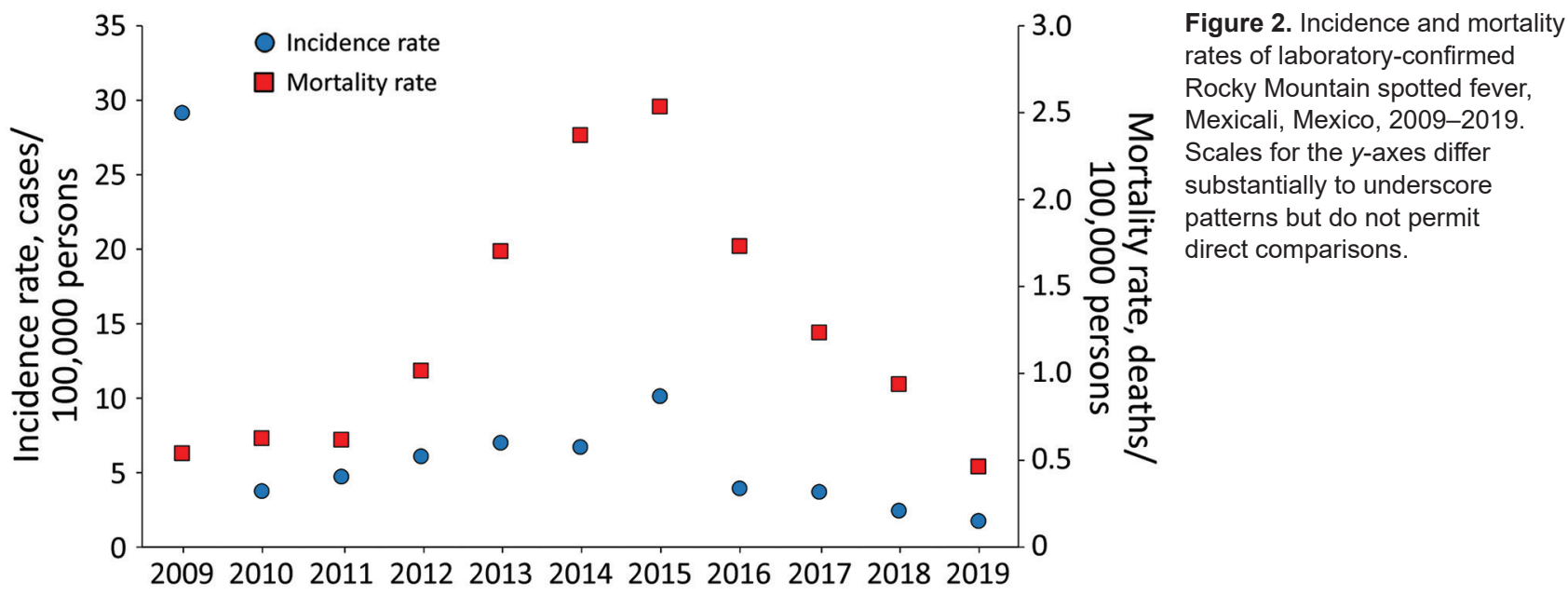




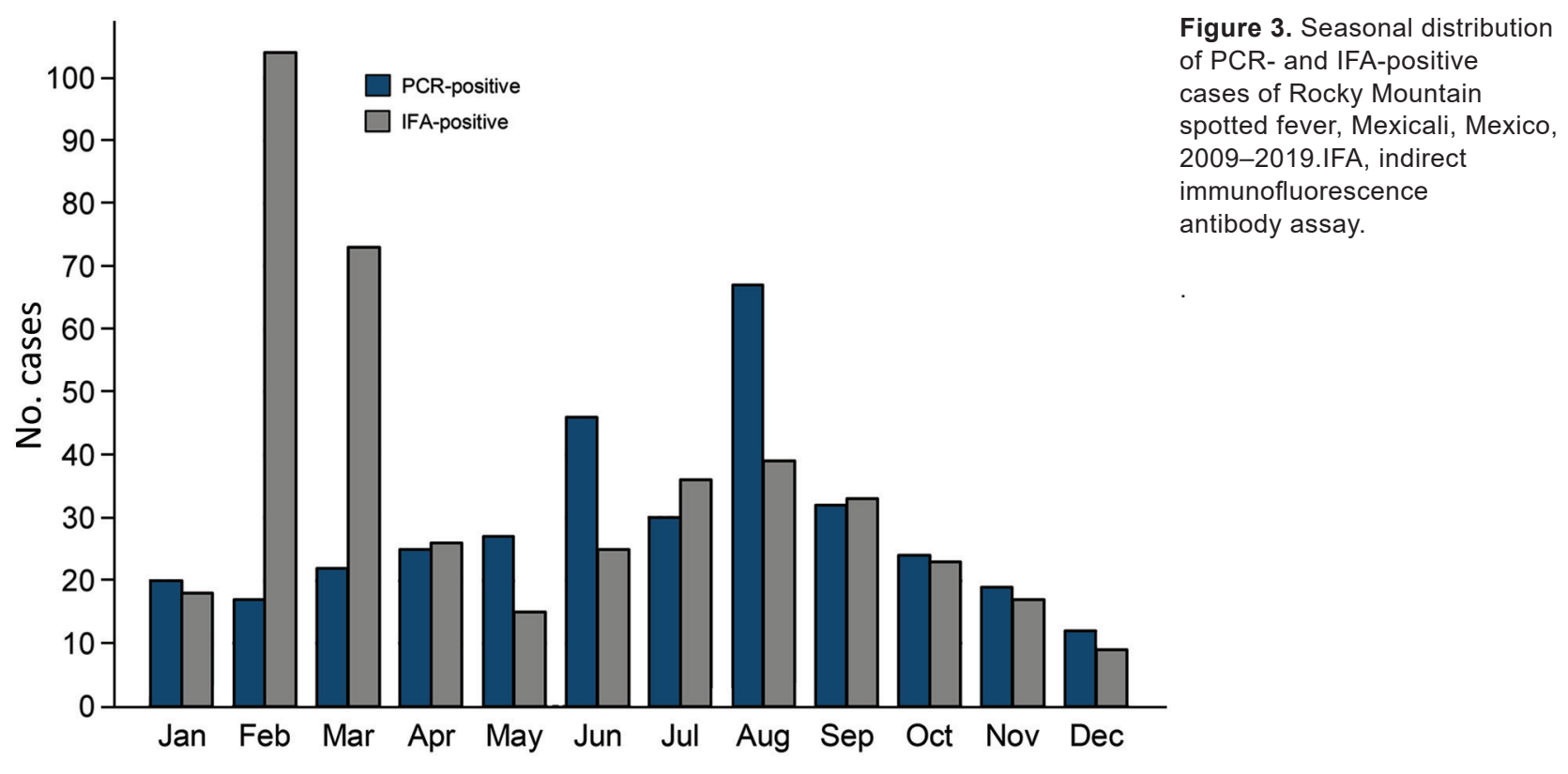

Mexicali Valley. By comparison, the largest modern outbreak of RMSF in the United States, involving 466 confirmed and probable cases during 2003-2019, has affected predominantly rural tribal communities in Arizona (https://www.azdhs.gov/preparedness/ epidemiology-disease-control/index.php\#data-statspast-years). Urban foci of RMSF are described only rarely and sporadically in the United States and other countries of Latin America and are characteristically limited in size and duration (23-26), so the longevity, remarkably high prevalence, and multifocal distribution of RMSF in a large metropolitan center poses unprecedented public health challenges.

This study is also noteworthy for the large number of PCR-positive cases available for analysis. Various studies indicate that the clinical sensitivities of molecular assays are low early in the illness, but increase as the disease progresses and the patient becomes severely ill $(27,28)$. PCR-positive patients are more likely to have severe manifestations, which could bias comparisons between groups confirmed by molecular and serologic methods. In addition, the molecular assay used to confirm cases of RMSF in Mexicali is specific only for the genus Rickettsia (17); because other pathogenic Rickettsia species, including $R$. massiliae, $R$. parkeri, and $R$. typhi, are endemic to northern Mexico (29-33), some PCR-positive patients identified in this series might have represented cases of rickettsial diseases other than RMSF. However, the overall severity of illnesses, coupled with extensive and consistent epidemiologic and environmental evidence implicating brown dog ticks as the principal vector perpetuating this outbreak $(8-10,12)$, suggest strongly that most, if not all, PCR-confirmed cases were indeed infections caused by $R$. rickettsii.

Although IFA methods are used widely for epidemiologic evaluations of RMSF, the use of a single IgG titer can reflect past exposure to an SFGR at an undetermined time and can inaccurately reflect surveillance estimates that define the magnitude and clinical characteristics of RMSF (29). Because IgG titers are reflective of the host immune response to $R$. rickettsii, these titers are not expected to be elevated in the first several days of illness, when most patients seek medical attention. In fact, $\approx 50 \%$ of patients with RMSF lack

Table 2. Age distribution of patients with PCR- and IFA-positive cases of fatal Rocky Mountain spotted fever, Mexicali, Mexico, 2009-2019*

\begin{tabular}{lcccc}
\hline & & & No. (\%) & \\
\cline { 2 - 5 } Age group, $y$ & PCR-positive & IFA-positive & PCR- and IFA-positive & Total \\
\hline$\leq 15$ & $25(20)$ & $6(54.55)$ & $1(25)$ & $32(22.86)$ \\
$16-24$ & $25(20)$ & 0 & 0 & $25(17.86)$ \\
$25-44$ & $43(34.40)$ & $3(27.27)$ & $2(50)$ & $48(34.29)$ \\
$45-64$ & $28(22.40)$ & $2(18.18)$ & $1(25)$ & $31(22.14)$ \\
$\geq 65$ & $4(3.20)$ & 0 & $4(100)$ & $4(2.86)$ \\
\hline Total & $129(100)$ & $11(100)$ & & $140(100)$ \\
\hline *IFA, indirect immunofluorescence antibody assay. & & & \\
\hline
\end{tabular}


Table 3. Demographic and clinical characteristics of patients with PCR- and IFA-positive cases of Rocky Mountain spotted fever, Mexicali, Mexico, 2009-2019*

\begin{tabular}{|c|c|c|c|c|}
\hline Characteristic & Total & PCR-positive & IFA-positive & $p$ value \\
\hline No. patients & 759 & 341 & 418 & \\
\hline \multicolumn{5}{|l|}{ Sex } \\
\hline $\mathrm{F}$ & $433(57.05)$ & $170(49.85)$ & $263(62.92)$ & $<0.001$ \\
\hline$M$ & $326(42.95)$ & $171(50.15)$ & $155(37.08)$ & \\
\hline Age, y (mean \pm SD) & $23.94( \pm 17.67)$ & $24.38( \pm 18.89)$ & $23.59( \pm 16.62)$ & 0.540 \\
\hline Hospitalized & $394(51.91)$ & $271(79.47)$ & $123(29.43)$ & $<0.001$ \\
\hline Died & $136(17.92)$ & $125(36.66)$ & $11(2.63)$ & $<0.001$ \\
\hline \multicolumn{5}{|l|}{ Signs and symptoms } \\
\hline Fever & $759(100)$ & $341(100)$ & $418(100)$ & 0.999 \\
\hline Headache & $656(86.43)$ & $288(84.46)$ & 368 (88.04) & 0.166 \\
\hline Myalgia & $468(61.66)$ & $229(67.16)$ & $239(57.18)$ & 0.005 \\
\hline Arthralgia & 403 (53.10) & $197(57.77)$ & $206(49.28)$ & 0.023 \\
\hline Retro orbital pain & $82(10.80)$ & $26(7.04)$ & $58(13.88)$ & 0.003 \\
\hline Rash & $328(43.27)$ & $181(53.24)$ & $147(35.17)$ & $<0.001$ \\
\hline Pruritis & $139(18.31)$ & $56(16.42)$ & $83(19.86)$ & 0.258 \\
\hline Vomiting & $322(42.42)$ & $188(55.13)$ & $134(32.06)$ & $<0.001$ \\
\hline Nausea & $366(48.22)$ & $206(60.41)$ & $160(38.28)$ & $<0.001$ \\
\hline Chills & $274(36.10)$ & $127(37.24)$ & $147(35.17)$ & 0.595 \\
\hline Photophobia & $78(10.28)$ & $29(8.50)$ & $49(11.72)$ & 0.152 \\
\hline Abdominal pain & $345(45.45)$ & $191(56.01)$ & $154(36.84)$ & $<0.001$ \\
\hline Diarrhea & $188(24.77)$ & $112(32.84)$ & $76(18.18)$ & $<0.001$ \\
\hline Conjunctivitis & $110(14.49)$ & $40(11.73)$ & $70(16.75)$ & 0.062 \\
\hline Nasal congestion & $109(14.36)$ & $34(9.97)$ & $75(17.94)$ & 0.002 \\
\hline Cough & $189(24.93)$ & $72(21.18)$ & $117(27.99)$ & 0.035 \\
\hline Pharyngitis & $156(20.58)$ & $69(20.23)$ & $87(20.86)$ & 0.857 \\
\hline Rhinitis & $106(13.97)$ & $34(9.97)$ & $72(17.22)$ & 0.004 \\
\hline Hepatomegaly & $68(8.96)$ & $44(12.90)$ & $24(5.74)$ & 0.001 \\
\hline Splenomegaly & $31(4.08)$ & $21(6.16)$ & $10(2.39)$ & 0.010 \\
\hline Adenomegaly & $17(2.24)$ & $7(2.05)$ & $10(2.39)$ & 0.810 \\
\hline Jaundice & $40(5.27)$ & $26(7.62)$ & $14(3.35)$ & 0.013 \\
\hline Hemorrhage & $87(11.46)$ & $60(17.60)$ & $27(6.46)$ & $<0.001$ \\
\hline Seizures & $32(4.22)$ & $30(8.80)$ & $2(0.48)$ & $<0.001$ \\
\hline
\end{tabular}

a diagnostically relevant IFA titer (i.e., $>64$ ) during the first week of illness (34). In addition, $\geq 50 \%$ of all deaths attributed to $R$. rickettsii occur within 7-9 days after illness, which explains the large percentage of persons who die from RMSF without serologic confirmation (35). In this investigation, approximately two thirds of the IFA-confirmed case-patients for whom an illness onset date was recorded had a titer at or above the threshold value for a positive result during the first week of illness. For these reasons, we compared PCR-positive cases to those with only a positive IFA result and identified substantial differences between these groups. The clinical characteristics of PCRpositive case-patients in Mexicali matched closely with those described for well-characterized series from Arizona, USA, and Coahuila and Sonora, Mexico $(3,22,36,37)$. In contrast, case-patients with a single IgG titer were less likely to demonstrate many of the classical characteristics of RMSF, including rash, myalgia, abdominal pain, nausea, and vomiting. In addition, the frequencies of hospitalization, jaundice, hemorrhages, seizures, and death were each less common for IFA-positive case-patients. These findings indicate that some or many cases defined by a single positive antibody titer do not accurately reflect the clinical profile of RMSF in Mexico, and that subsequent case definitions for RMSF should require confirmation by molecular methods specific for $R$. rickettsii, or a $\geq 4$ fold rise in IgG titers between paired serum samples.

Because IgG titers reactive with $R$. rickettsii can persist in some persons for $>1$ year after resolution of the acute infection, some, or perhaps many, of the IFApositive cases could represent patients exposed to or infected remotely with an SFGR who sought treatment for other febrile, rash-associated diseases endemic to northern Mexico, including dengue, Zika virus infection, or leptospirosis (13). Furthermore, we excluded from our analyses $\approx 1,600$ probable case-patients for whom laboratory tests were negative; nonetheless, some, or perhaps many, of these probable cases reflected actual cases of RMSF, particularly those in patients tested early in the course of disease and for whom PCR or IFA methods were unable to detect rickettsial DNA or antibodies reactive with $R$. rickettsii. Collectively, these situations could skew frequencies of clinical characteristics and case-fatality rates, pose limitations to the tabulation of actual cases, and preclude accurate assessment of the incidence of RMSF in Mexicali during the period of study. 

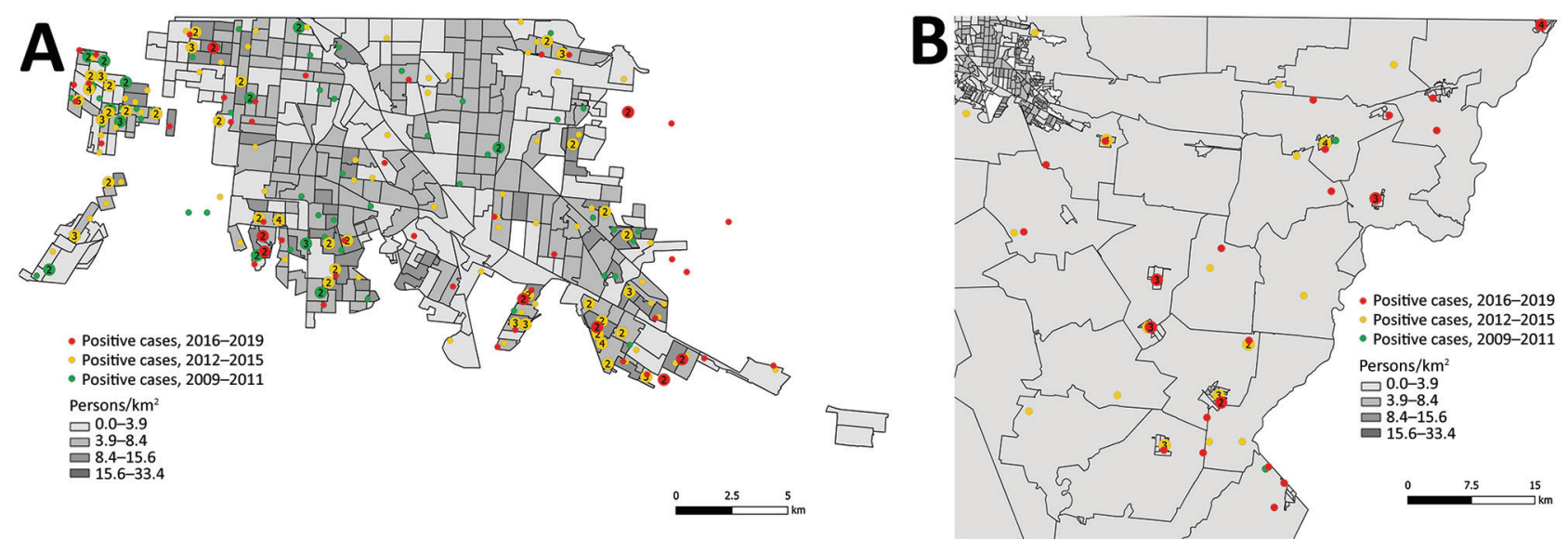

Figure 4. Geographic distribution of all PCR-positive cases of Rocky Mountain spotted fever in Mexicali (A) and the Mexicali Valley (B), Mexico, 2009-2019. Outlined areas represent census-related Basic Geostatistical areas established by the Mexico's National Institute of Statistics and Geography. Numbers in circles represent the number of cases in each location.

During 2009-2019, several hundred foci of RMSF emerged and recurred within multiple neighborhoods across the city of Mexicali, suggesting a transition from epidemic to hyperendemic disease. Similarly concerning is the more recent recognition of RMSF among smaller rural communities of the Mexicali Valley. The longevity and multifocal distribution of RMSF in Mexicali underscore many of the complex challenges faced by public health authorities in this expansive urban setting. Achieving a level of acceptable risk will require coordinated and sustained control and prevention strategies that diminish substantially the numbers of $R$. rickettsii-infected $R h$. sanguineus s.l. ticks and free-roaming and stray dogs across a densely populated region covering $>100 \mathrm{~km}^{2}$. Because brown dog ticks are predominantly endophilic and spend $\approx 95 \%$ of their life hidden in structural cracks and crevices of human habitations and surrounding structures, this species can be notoriously difficult to control. Surreptitious infestations and high fecundity rates can result in explosive increases in Rh. sanguineus s.l. tick populations. Acaricides that contain pyrethoids, including permethrin and cypermethrin, are commonly used in these peridomestic settings because of their relative safety to nontarget species; nonetheless, resistance to these compounds has been identified recently among some brown dog tick populations in Mexico (38).

The ecology of RMSF in Mexicali, as in other regions of the southwestern North America with hyperendemic or epidemic levels of disease, is linked inextricably to an overabundance of tick-infested free-ranging and stray dogs in affected communities $(3,4,10-13,19,39)$. Results of a citywide canine serosurvey conducted in Mexicali in 2017 identified antibodies reactive to $R$. rick- ettsii in $65 \%$ of 213 owned dogs, and $55 \%$ of all examined animals were infested with brown dog ticks (10). Levels of tick infestation and exposure to $R$. rickettsii are likely even greater among stray dogs $(30,39)$. Movement of free-ranging, tick-infested canines within and among neighborhoods could contribute to multifocal recurrences of RMSF identified in Mexicali during the 11 -year study period. Community-based interventions that provide and apply long-acting, acaracide-impregnated collars to large numbers of dogs can bring about rapid and substantial declines in canine and environmental tick populations and cases of RMSF among community inhabitants $(10,40)$. Nonetheless, the distribution of stray dogs in cities correlates closely with high-density, low-income areas, and sustained interventions are prohibitively expensive for most affected neighborhoods (40). In this context, funding from state, national, or international agencies is needed to establish and maintain collaring activities, animal control, and spay and neuter programs that reduce the amplification of brown dog ticks and $R$. rickettsii.

In conclusion, intensified clinical and public education on the regional ecology of RMSF in Mexicali, and the necessity for rapid diagnosis and appropriate treatment, are of paramount importance as the outbreak in this location continues. The emergence and perpetuation of RMSF in Mexicali and in several other states of northern Mexico are not isolated or anomalous outbreaks but rather should be considered harbingers of national or even international concern (41). The enormous human and economic costs associated with epidemic RMSF will undoubtedly continue without adoption and use of well-supported and carefully integrated efforts that directly address this public health emergency. 


\section{Acknowledgments}

We thank Krystal Bejarano from ISESALUD for assistance with data collection.

\section{About the Author}

Dr. Zazueta is the state epidemiologist in Baja California, Mexico, and holds an academic appointment at the Autonomous University of Baja California. His research interests include the enhancement of surveillance systems for infectious diseases, with a focus on improving understanding of behavioral, biological, and social determinants of emerging diseases in developing countries.

\section{References}

1. Hattwick MA, O'Brien RJ, Hanson BF. Rocky Mountain spotted fever: epidemiology of an increasing problem. Ann Intern Med. 1976;84:732-9. https:/ / doi. org/10.7326/0003-4819-84-6-732

2. Linnemann CC Jr, Jansen P, Schiff GM. Rocky Mountain spotted fever in Clermont County, Ohio: description of an endemic focus. Am J Epidemiol. 1973;97:125-30. https://doi.org/10.1093/oxfordjournals.aje.a121489

3. Demma LJ, Traeger MS, Nicholson WL, Paddock CD, Blau DM, Eremeeva ME, et al. Rocky Mountain spotted fever from an unexpected tick vector in Arizona. N Engl J Med. 2005;353:587-94. https://doi.org/10.1056/NEJMoa050043

4. Drexler N, Miller M, Gerding J, Todd S, Adams L, Dahlgren FS, et al. Community-based control of the brown dog tick in a region with high rates of Rocky Mountain spotted fever, 2012-2013. PLoS One. 2014;9:e112368. https://doi.org/10.1371/journal.pone.0112368

5. Martínez-Medina MA, Alvarez-Hernández G, Padilla-Zamudioa JG, Rojas-Guerra MG. Fiebre manchada de las Montañas Rocosas en niños: consideraciones clínicas y epidemiológicas. Gac Med Mex. 2007;143:137-40.

6. Alvarez-Hernandez G, Murillo-Benitez C, Candia-Plata MC, Moro M. Clinical profile and predictors of fatal Rocky Mountain spotted fever in children from Sonora, Mexico. Pediatr Infect Dis J. 2015;34:125-30. https:/ / doi.org/10.1097/ INF.0000000000000496

7. Bustamante-Moreno J, Pon-Mendez A. Actualización en la vigilancia epidemiologica de "Rickettsiosis". Epidemio Bol. 2010;27:14.

8. Eremeeva ME, Zambrano ML, Anaya L, Beati L, Karpathy SE, Santos-Silva MM, et al. Rickettsia rickettsii in Rhipicephalus ticks, Mexicali, Mexico. J Med Entomol. 2011;48:418-21. https://doi.org/10.1603/ME10181

9. Tinoco-Gracia L, Lomelí MR, Hori-Oshima S, Stephenson N, Foley J. Molecular confirmation of Rocky Mountain spotted fever epidemic agent in Mexicali, Mexico. Emerg Infect Dis. 2018;24:1723-5. https:// doi.org/10.3201/eid2409.171523

10. Foley J, Tinoco-Gracia L, Rodriguez-Lomelí M, Estrada-Guzmán J, Fierro M, Mattar-Lopez E, et al. Unbiased assessment of abundance of Rhipicephalus sanguineus sensu lato ticks, canine exposure to spotted fever group Rickettsia, and risk factors in Mexicali, México. Am J Trop Med Hyg. 2019;101:22-32. https:// doi.org/10.4269/ajtmh.18-0878

11. Nicholson WL, Paddock CD, Demma L, Traeger M, Johnson B, Dickson J, et al. Rocky Mountain spotted fever in Arizona: documentation of heavy environmental infestations of Rhipicephalus sanguineus at an endemic site. Ann N Y Acad
Sci. 2006;1078:338-41. https://doi.org/10.1196/ annals.1374.065

12. Tinoco-Gracia L, Quiroz-Romero H, Quintero-Martínez MT, Rentería-Evangelista TB, González-Medina Y, Barreras-Serrano A, et al. Prevalence of Rhipicephalus sanguineus ticks on dogs in a region on the Mexico-USA border. Vet Rec. 2009;164:59-61. https:/ / doi.org/10.1136/ vr.164.2.59

13. Álvarez-Hernández G, Roldán JFG, Milan NSH, Lash RR, Behravesh CB, Paddock CD. Rocky Mountain spotted fever in Mexico: past, present, and future. Lancet Infect Dis. 2017;17:e189-96. https:/ / doi.org/10.1016/ S1473-3099(17)30173-1

14. Instituto Nacional para el Federalismo y el Desarrollo Municipal. Principales datos socioeconomicos por municipio [cited 2021 Jan 15]. http:/ / www.inafed.gob.mx/es/inafed/ Principales_Datos_Socioeconomicos_por_Municipio.

15. Secretaría de salud. Subsecretaría de Prevención y Promoción a la Salud. Dirección General de Epidemiología. Manual de procedimientos estandarizados para la vigilancia epidemiológica de las enfermedades transmitidas por vectores (ETV). 2017 [cited 2021 Jan 15]. https:/ / epidemiologia.salud.gob.mx/gobmx/salud/ documentos/manuales/36_Manual_ETV

16. Instituto de Diagnóstico y Referencia Epidemiologicos. Guidelines for the laboratory surveillance of rickettsial diseases. Mexico City: Ministry of Health, 2017.

17. Stenos J, Graves SR, Unsworth NB. A highly sensitive and specific real-time PCR assay for the detection of spotted fever and typhus group Rickettsiae. Am J Trop Med Hyg. 2005;73:1083-5. https://doi.org/10.4269/ajtmh.2005.73.1083

18. Bustamante ME, Varela G. Una nueva rickettsiosis en México. Existencia de la fiebre manchada americana en los estados de Sinaloa y Sonora. Rev Inst Salubr Enferm Trop. 1943;4:189-211.

19. Bustamante ME, Varela G, Ortiz-Mariotte C. Estudios de fiebre manchada en México. Fiebre manchada en La Laguna. Rev Inst Salubr Enferm Trop. 1946;7:39-49.

20. De Lara Huerta J, Barragán RC. Fiebre manchada de las Montañas Rocosas en pediatría. Revisión clínica de una serie de 115 casos. Rev Enf Inf Ped. 2008;22:4-9.

21. Álvarez-Hernández G, Candia-Plata MC, Delgado-de la Mora J, Acuña-Meléndrez NH, Vargas-Ortega AP, Licona-Enríquez JD. Fiebre maculosa de las Montañas Rocosas en niños y adolescentes mexicanos: cuadro clínico y factores de mortalidad. Salud Publica Mex. 2016;58:385-92. https://doi.org/10.21149/spm.v58i3.7908

22. López-Castillo DC, Vaquera-Aparicio D, González-Soto MA, Martínez-Ramírez R, Rodríguez-Muñoz L, Solórzano-Santos F. Fiebre manchada de montañas rocosas: experiencia en 5 años de vigilancia activa en un hospital pediátrico de segundo nivel en el noreste de México. Bol Med Hosp Infant Mex. 2018;75:303-8.

23. Salgo MP, Telzak EE, Currie B, Perlman DC, Litman N, Levi M, et al. A focus of Rocky Mountain spotted fever within New York City. N Engl J Med. 1988;318:1345-8. https:/ / doi.org/10.1056/NEJM198805263182101

24. Argüello AP, Hun L, Rivera P, Taylor L. A fatal urban case of Rocky Mountain spotted fever presenting an eschar in San Jose, Costa Rica. Am J Trop Med Hyg. 2012;87:345-8. https:// doi.org/10.4269/ajtmh.2012.12-0153

25. Nasser JT, Lana RC, Silva CM, Lourenço RW, da Cunha e Silva DC, Donalísio MR. Urbanization of Brazilian spotted fever in a municipality of the southeastern region: epidemiology and spatial distribution. Rev Bras Epidemiol. 2015;18:299-312. https:/ / doi.org/10.1590/1980-5497201500020002 
26. Martínez-Caballero A, Moreno B, González C, Martínez G, Adames M, Pachar JV, et al. Descriptions of two new cases of Rocky Mountain spotted fever in Panama, and coincident infection with Rickettsia rickettsii in Rhipicephalus sanguineus s.l. in an urban locality of Panama City, Panama. Epidemiol Infect. 2018;146:875-8. https:/ / doi.org/10.1017/ S0950268818000730

27. Tzianabos T, Anderson BE, McDade JE. Detection of Rickettsia rickettsii DNA in clinical specimens by using polymerase chain reaction technology. J Clin Microbiol. 1989;27:2866-8. https:/ / doi.org/10.1128/JCM.27.12.28662868.1989

28. Kato C, Chung I, Paddock C. Estimation of Rickettsia rickettsii copy number in the blood of patients with Rocky Mountain spotted fever suggests cyclic diurnal trends in bacteraemia. Clin Microbiol Infect. 2016;22:394-6. https:/ / doi.org/10.1016/ j.cmi.2015.12.019

29. Straily A, Stuck S, Singleton J Jr, Brennan S, Marcum S, Condit M, et al. Antibody titers reactive with Rickettsia rickettsii in blood donors and implications for surveillance of spotted fever rickettsiosis in the United States. J Infect Dis. 2020;221:1371-8. https://doi.org/10.1093/infdis/jiz316

30. Pieracci EG, De La Rosa JDP, Rubio DL, Perales MES, Contreras MV, Drexler NA, et al. Seroprevalence of spotted fever group rickettsiae in canines along the United StatesMexico border. Zoonoses Public Health. 2019;66:918-26. https:// doi.org/10.1111/zph.12642

31. López-Pérez AM, Sánchez-Montes S, Foley J, Guzmán-Cornejo C, Colunga-Salas P, Pascoe E, et al. Molecular evidence of Borrelia burgdorferi sensu stricto and Rickettsia massiliae in ticks collected from a domestic-wild carnivore interface in Chihuahua, Mexico. Ticks Tick Borne Dis. 2019;10:1118-23. https:/ / doi.org/10.1016/ j.ttbdis.2019.05.018

32. Delgado-de la Mora J, Sánchez-Montes S, Licona-Enríquez JD, Delgado-de la Mora D, Paddock CD, Beati L, et al. Rickettsia parkeri and Candidatus Rickettsia andeanae in ticks of the Amblyomma maculatum group, Mexico. Emerg Infect Dis. 2019;25:836-8. https://doi.org/10.3201/eid2504.181507

33. Lopéz-Pérez AM, Chaves A, Sánchez-Montes S, Foley P, Uhart M, Barrón-Rodríguez J, et al. Diversity of rickettsiae in domestic, synanthropic, and sylvatic mammals and their ectoparasites in a spotted fever-epidemic region at the western US-Mexico border. Transbound Emerg Dis 2021; Mar 5. PubMed https:/ / doi.org/10.1111/tbed.14027

34. Kleeman KT, Hicks JL, Anacker RL, Philip RN, Casper EA, Hechemy KE, et al. Early detection of antibody to Rickettsia rickettsii: a comparison of four serological methods; indirect hemagglutination, indirect fluorescent antibody, latex agglutination, and complement fixation. In: Burgdorfer W, Anacker RL, editors. Rickettsiae and rickettsial diseases. New York: Academic Press, Inc.; 1981. p. 171-8.

35. Paddock CD, Greer PW, Ferebee TL, Singleton J Jr, McKechnie DB, Treadwell TA, et al. Hidden mortality attributable to Rocky Mountain spotted fever: immunohistochemical detection of fatal, serologically unconfirmed disease. J Infect Dis. 1999;179:1469-76. https://doi.org/10.1086/314776

36. Delgado-De la Mora J, Licona-Enríquez JD, Leyva-Gastélum M, Delgado-De la Mora D, Rascón-Alcantar A, Álvarez-Hernández G. Una serie de casos fatales de fiebre manchada de las Montañas Rococsas en Sonora, México. Biomedica. 2018;38:69-76. https://doi.org/10.7705/ biomedica.v38i0.3507

37. Alvarez D, Ochoa E, Nichols Heitman K, Binder AM, Alvarez G, Armstrong PA. Epidemiology and clinical features of Rocky Mountain spotted fever from enhanced surveillance, Sonora, Mexico: 2015-2018. Am J Trop Med Hyg. 2020;104:190-7. https:// doi.org/10.4269/ajtmh.20-0854

38. Rodriguez-Vivas RI, Ojeda-Chi MM, Trinidad-Martinez I, Bolio-González ME. First report of amitraz and cypermethrin resistance in Rhipicephalus sanguineus sensu lato infesting dogs in Mexico. Med Vet Entomol. 2017;31:72-7. https://doi.org/10.1111/mve.12207

39. Ortega-Morales AI, Nava-Reyna E, Ávila-Rodríguez V, González-Álvarez VH, Castillo-Martínez A, Siller-Rodríguez QK, et al. Detection of Rickettsia spp. in Rhipicephalus sanguineus (sensu lato) collected from free-roaming dogs in Coahuila State, northern Mexico. Parasit Vectors. 2019;12:130. https:/ / doi.org/10.1186/ s13071-019-3377-z

40. Alvarez-Hernandez G, Drexler N, Paddock CD, Licona-Enriquez JD, la Mora JD, Straily A, et al. Communitybased prevention of epidemic Rocky Mountain spotted fever among minority populations in Sonora, Mexico, using a One Health approach. Trans R Soc Trop Med Hyg. 2020;114:293300. https:/ / doi.org/10.1093/trstmh/trz114

41. Drexler NA, Yaglom H, Casal M, Fierro M, Kriner P, Murphy B, et al. Fatal Rocky Mountain spotted fever along the United States-Mexico border, 2013-2016. Emerg Infect Dis. 2017;23:1621-6. https:// doi.org/10.3201/eid2310.170309

Address for correspondence: Oscar E. Zazueta, Av. Pioneros 1005, Centro Cívico, Mexicali, B.C. 21000, Mexico; email: oez512@mail.harvard.edu 